\title{
Non-recurrent laryngeal nerve
}

\author{
Fahri Yetișir, Alper Bilal Özkardeș, Halit Ziya Dündar, Bozkurt Birkan, Ahmet Burak Çiftci, Mehmet Kılıç
}

ABSTRACT Injury to the recurrent laryngeal nerve is a serious complication in thyroid and parathyroid surgery. The anatomy of the recurrent laryngeal nerve is variable. Non-recurrent nerve is a very rare variation of the inferior laryngeal nerve. Because of the anatomical variations of the nerve, preservation of the nerve is the optimal strategy during surgery. In this case report, we present a non-recurrent laryngeal nerve abnormality in a patient who underwent parathyroidectomy, thyroidectomy and functional neck dissection for malignant parathyroid disease. A non-recurrent laryngeal nerve was identified during nerve exploration.

Key Words: Parathyroid, non-recurrent laryngeal nerve, inferior laryngeal nerve

Clinic of General Surgery, Ministry of Health Ankara Etlik Training Hospital, Ankara, Turkey

This case was presented at the $5^{\text {th }}$ National Endocrine Surgery Congress, 24-27 April 2011, Antalya, Turkey.

\section{Address for Correspondence Dr. Fahri Yetişir \\ Clinic of General Surgery, Ministry of Health Ankara Etlik Training Hospital, Ankara, Turkey Phone.: +9031221980 62 e-mail: \\ drfahriyetisir@hotmail.com}

Received: 15.08.2011

Accepted: 31.10 .2011

Online Available Date: 28.05.2013

CCopyright 2014 by Turkish Surgical Association

Available online at www.ulusalcerrahidergisi.org

\section{INTRODUCTION}

The recurrent laryngeal nerves course on both sides of the trachea, and at the point of entrance to the larynx they are located just lateral to the Berry ligament. They have important anatomic variations. Very rarely, the inferior laryngeal nerve exits the vagal nerve in the cervical region and enters the larynx with a short and straight course from its origin. This anomaly is called "non-recurrent laryngeal nerve" (1-3). The incidence of non-recurrent laryngeal nerve is $0.5-1 \%$ on the right side, and it is even rarer on the left (3-5). This anomaly arises as a result of vascular anomalies that develop during embryonic stage $(1,2,6)$. The presence of aberrant subclavian artery or absence of innominate artery may be associated with right non-recurrent laryngeal nerve. Anomalies accompanying left non-recurrent laryngeal nerve are situs inversus and right-sided aortic arch (1,2). There are three types of non-recurrent laryngeal nerve. Type-1: courses closely to the superior thyroid vessels. Type-2 (Type-2A): courses parallel to the inferior thyroid artery and transversely above the artery. Type-3 (Type-2B) courses parallel to the inferior thyroid artery, and transversely between branches of or under the inferior thyroid artery (7).

The easiest place to reach the inferior laryngeal nerve during nerve exploration is the region where it courses in close relation to the inferior thyroid artery. While its dissection is more difficult, due to the fixed anatomic location of the non-recurrent laryngeal nerve, a recurrent laryngeal nerve can be observed at the level of the Berry ligament. In order to prevent damage to the nerve during dissection, the nerve could be palpated at the level of the lower pole like a string for locating the nerve $(8,9)$.

\section{CASE PRESENTATION}

A 35-year-old woman who was evaluated for joint pain had a serum calcium level of $14.5 \mathrm{mEq} / \mathrm{mL}$, and PTH: 1250. Her neck ultrasonography showed the right thyroid lobe to be $18 \times 20 \times 40 \mathrm{~mm}$, and the left lobe $9 \times 14 \times 32 \mathrm{~mm}$. A $26 \times 28 \times 41 \mathrm{~mm}$ in size, heterogeneous hypoechoic lesion with peripheral vascularization was observed behind the right thyroid lobe. After obtaining informed consent, the scintigraphy revealed uptake covering most of the right thyroid that was compatible with parathyroid adenoma, and the patient underwent right thyroid lobectomy and parathyroidectomy on 11 October 2010 with a preliminary diagnosis of parathyroid adenoma. Recurrent laryngeal nerve exploration during this operation showed a Type-1 non-recurrent laryngeal nerve on the right side. The patient's pathology evaluation was reported as parathyroid carcinoma, and on ultrasonography cervical lymphadenopathy was observed on the right. A second operation for right functional neck dissection was performed on 21 October 2010. Meanwhile anatomical structures were exposed and the non-recurrent vagal nerve that was determined at the previous operation was dissected by opening the carotid sheath to the point of its origin from the vagus and was preserved (Figure 1-3). During the operation, multiple lymphadenopathies were present at cervical chain levels 3 and 4 and were dissected together with the adipose tissue. The patient had symptoms of hypocalcemia on the first 3-4 postoperative days and was treated with oral and intravenous calcium. She was discharged with oral calcium and vitamin D3 treatments. 


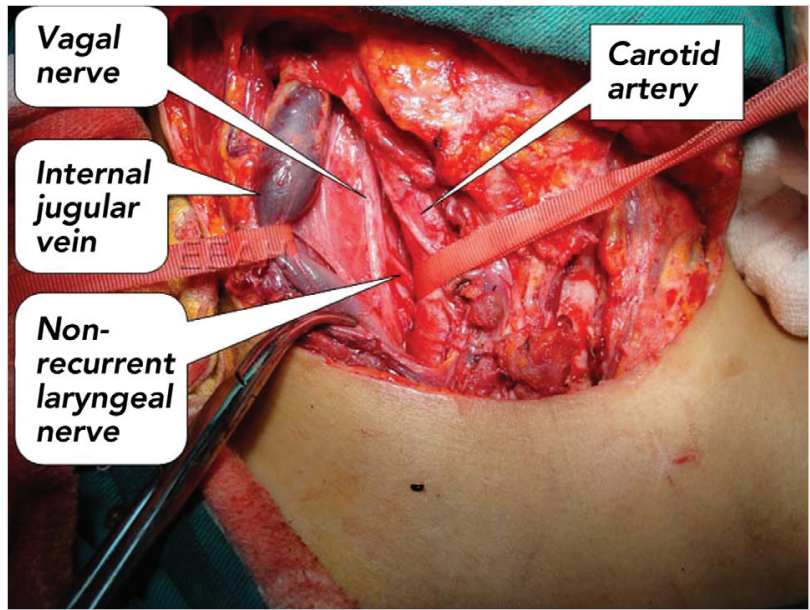

Figure 1. The carotid sheet is opened, carotid artery and internal jugular veins are identified and the origin of nonrecurrent laryngeal nerve is exposed

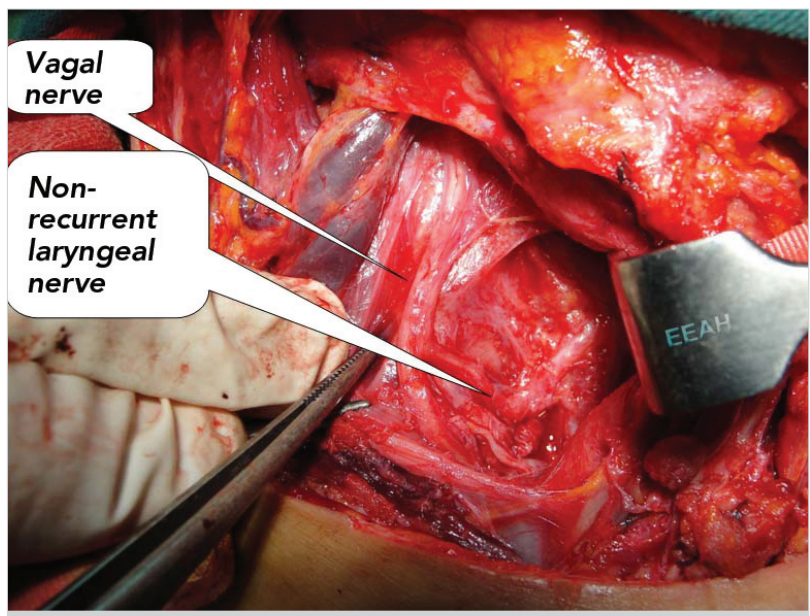

Figure 2. The origin of non-recurrent laryngeal nerve from the vagal nerve is exposed by medial retraction of the carotid artery and lateral retraction of the jugular vein

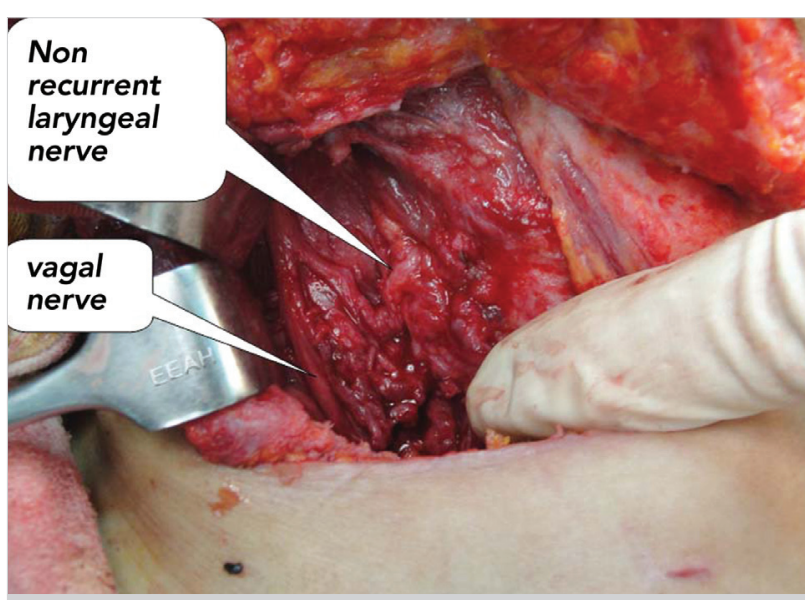

Figure 3. The course of non recurrent laryngeal nerve from the vagal nerve to the larynx

\section{DISCUSSION}

The most feared complication of thyroidectomy and parathyroidectomy is recurrent laryngeal nerve injury. Recurrent laryngeal nerve is known to have many anatomical variations (1-3, 10). Rarely, a non-recurrent laryngeal nerve can be observed.
It is expressed that due to these anatomical differences, a safe area to be operated cannot be defined without visualizing the nerve (10). The right subclavian artery anomaly can be determined by preoperative neck ultrasonography, thus detecting patients with a right non-recurrent nerve (5).

\section{CONCLUSION}

Many experienced surgeons emphasize that visualization of the recurrent laryngeal nerve during dissection for thyroidectomy and parathyroidectomy is crucial in order to minimize the possibility of injury. Recently, many studies indicated that nerve injury is less frequent in patients with recurrent laryngeal nerve exploration (7, 10-17). In our opinion, compatible with the current approach, standard dissection of the nerve will avoid nerve injury.

Informed Consent: Written informed consent was obtained patient who participated in this case.

Peer-review: Externally peer-reviewed.

Author Contributions: Study concept and design - F.Y., M.K.; Acquisition of data - F.Y., B.Ç., H.Z.D.; Analysis and interpretation of data - F.Y., M.K., B.B.; Preparation of the manuscript - F.Y.

Conflict of Interest: No conflict of interest was declared by the authors.

Financial Disclosure: The authors declared that this study has received no financial support.

\section{REFERENCES}

1. John B. Hanks. Tiroid, in: Textbook of surgery. Edited by Sabiston.17nd Edition, Nobel Tıp Kitapevleri Ltd. Şti. 2010.pp.947983.

2. Geeta Lal, Clark OH, :Thyroid and parathyroid, In: Principles of surgery. Edited by Schwartz SI, Eighth Edition, Newyork, Mc Graw Hill, 2005.pp.1445-526.

3. Skandalakis JE, Skandalakis PN, Skandalakis LJ. Surgical Anatomy and Technique. 2nd Edition, İstanbul, Nobel Tıp Kitapevi, 2000.

4. Kayhan C, Yiğitler C, Yılmaz F, Yıldız M, Uzar Al, Arslan I. The effect of recurrent laryngeal nerve dissection on morbidity. Ankara Cerrahi Dergisi 1999; 4: 219-222.

5. Yetisir F, Salman AE, Çiftçi B, Teber A, Kiliç M. Efficacy of ultrasonography in identification of non-recurrent laryngeal nerve. Int J Surg 2012; 10: 506-509.

6. Pisanu A, Pili S, Uccheddu A. Non-recurrent inferior laryngeal nerve. Chir Ital 2002; 54: 7-14.

7. Toniato A, Mazzarotto R, Piotto A, Bernante P, Pagetta C, Pelizzo $M R$. Identification of the nonrecurrent laryngeal nerve during thyroid surgery: 20-year experience. World J Surg 2004; 28: 659-661.

8. Kasemsuwan L, Nubthuenetr S. Recurrent laryngeal nerve paralysis: a complication of thyroidectomy. J Otolaryngol 1997; 26: 365367.

9. de Roy van Zuidewijn DB, Songun I, Kievit J, van de Velde CJ. Complications of thyroid surgery. Ann Surg Oncol 1995; 2: 56-60.

10. İşgör A. Thyroid diseases and Surgery. İstanbul, Avrupa Kitapçılık 2000.p.551-581.

11. Li X, Wang Z, Lu X, Li J, Huang Y, Huang J, Long X. Non-recurrent laryngeal nerve related to thyroid surgery: a report of 5 cases and literature review. Med Sci Monit 2010; 16: CS71-5.

12. Page $C$, Monet $P$, Peltier J, Bonnaire B, Strunski V. Non-recurrent laryngeal nerve related to thyroid surgery: report of three cases. $J$ Laryngol Otol 2008; 122: 757-761. 
Yetişir et al.

Non-recurrent laryngeal nerve

13. Spartà C, Cossu ML, Fais E, Palermo M, Cossu F, Ruggiu M, et al. Non-recurrent inferior laryngeal nerve: anatomy, frequency and surgical considerations. Minerva Chir 2004; 59: 555-561.

14. Sciumè C, Geraci G, Pisello F, Li Volsi F, Facella T, Licata A, et al. Non recurrent laryngeal nerve. Personal experience. G Chir 2005; 26: 434-437.

15. Iura E, Sanders RL, Cady RB. Surgical complications and their management, In: Surgery of the Thyroid and Parathyroid Glands,
Edited by Cady B, Rossi RL. Philadelphia, WB. Saunders Company 1991.p.326-336.

16. Flynn MB, Lyons KJ, Tarter JW, Ragsdale TL. Local complications after surgical resection for thyroid carcinoma. Am J Surg 1994; 168 404-407.

17. Aras $A$, Arslantürk $H$, Kotan Ç. Non-recurrent laryngeal nerve. Van Tıp Dergisi 2001; 8: 8. 